\title{
Albanian and English Hand in Hand Phraseologically
}

\author{
Arben Gaba \\ "Eqrem Çabej" University, Faculty of Education and Social Sciences, \\ Department of Foreign Languages, English Branch
}

\begin{abstract}
Phraseological expressions which contain at least one body-part are common in all the languages. In this paper we want to compare those kinds of expressions which are formed with the word dorë/duar in Albanian and hand in English. Our expressions are extracted both form monolingual and bilingual Albanian and English phraseological dictionaries. The expressions we have chosen are analysed from the cognitive standpoint, i.e. when we look at the expressions we try to gain an insight into how these two peoples, speaking languages which are distantly related and different in terms of organisation, see and conceptualize the world around them and as a result shape it linguistically. This process has undoubtedly attracted the attention of researchers (and the resulting ongoing debate) around the world. In order to see how comparable the world view and cultures of these two languages and peoples are we compare the syntactic and semantic structure of phraseological expressions containing the relevant body-part term.
\end{abstract}

Keywords:bBody part, phraseological expressions, Albanian, English, false friends

\section{Introduction}

Phraseological expressions are a very important part of the language of a people. Regardless of the various definitions given to them by different scholars, they express the same /or similar world conceptualisation realized in a way which is uniquely language-specific. So, phraseological expressions are no exception to this rule since they are part of the basic vocabulary of a people. Every language learner finds it difficult to get the hang of them since they comprise a huge chunk of the vocabulary of every language. As Wierzbicka puts it "The dictionary is a very sensitive indicator of the culture of a nation" ANNA WIERZBICKA (1997: p, iii). So, this means that whenever we compare languages, and by extension cultures, we also compare the various phraseological expressions they use. In doing this, we find how and if languages, which are distant from one another both geographically but also lingusitically, Albanian and English in our case, realize a particular semantic concept. This question served as our starting point to investigate phraseological expressions with the word dorë / duar in Albanian and hand in English. The aim of our paper is to investigate whether the word hand / dore is used in praselogical units with its basic meaning e.g. hand, (this limb as a representative of the person which performs something, causes something, or possesses something) and whether or not there are phraseological correspondences between Albanian and English containing this body-part term.

Before we proceed with our analysis we would like to say a few words regarding the terminology in this field. It is not the aim of our paper to discuss if and to what extent scholars agree on what is and is not a phraseological expression and why they go by various names but it is safe to say that opinions differ since such expressions display the richness and diversity of human language itself and tend to defy any attempt at categorising them a priori. And different designations are used for different expressions which share similar characteristics but which are different otherwise. Regarding their semantic unity we can say that they fall into a sliding scale ranging from the opaque (the famous kick the bucket) and fixed to transparent and variable (hard frost) with idiom taking pride of place, see Gläser (1998: 126). In our paper we will cast our phraseological net not so wide ( we deal with only one concept).

\section{Semantic analysis}

We start our semantic analysis by stating obviously that the word under question has a rich semantic structure in both languages, its senses are derivatives of the processes of the work of metaphor and metonymy which use as their jumping 
board this limb as a representative of the person which performs something, causes something, or possesses something. English has the phraseological upper hand for obvious reasons in terms of volume.

As far as the semantics of the phraseological units containing the body-part term "dorë" in Albanian is concerned, actually a small part of them express action where this body-part term is used in its conventional meaning and is, therefore, the doer of the action. The rest have other connotations ranging from carelessness, emotion, state of being, acquiring an ability, exploitation, artfulness, malice, negligence, ingratitude, lack of willingness, compassion, graft, theft and even loss.

First we present those expressions expressing action.

-Ngre (çon) dorë (dorën) (kundër dikujt a kundër diçkaje) (lift (raise) hand (the hand) (against someone or something); lift/raise one's hand against $s b)^{1}$

- I dha duart (dikujt) (gave (someone) the hands; kick out)

-la bëj me dorë (dikujt a diçkaje) (to wave one's hand (at someone or something);not to need someone or something anymore)

We continue with those expressions which express emotion, state of being, acquiring an ability, exploitation, artfulness, malice, negligence, ingratitude, lack of willingness, compassion, graft, theft and even loss.

-Hedh gurin e fsheh dorën (dikush) ((someone) flings the stone and hides the hand; commit a wrongdoing but deny responsibility)

-S'më bën dora (one's hand is unwilling to act, to pity someone or something; to be unwilling to do something)

-U bë një dorë (dikush) (became one hand (someone); to crouch out of fear, cold, problems)

-E ka dorën të shpuar (dikush) ((someone) has a pierced hand; to spend money recklessly)

-Syri plot e dora thatë (the eye is full but the hand is dry; to see a lot of things around but to be unable to buy)

-I nxjerr gështenjat (nga zjarri) me duart e botës (pull the chestnuts (out of the fire) with the world's hand; pull the Isomeone's chestnuts out of the fire).

Here we feel it is apropos to make a clarification, even though this seems to be the case of a total equivalence in fact we are dealing with a false friend which according to Dobrovol'skij (2005: p, 109), are "two or more expressions that evoke almost identical or very similar mental images but show significant differences in the actual meaning", thus the intended meaning of the expression in Albanian is to achieve something using someone else as a cat's paw, unlike the English which carries a different meaning.

-E ka prishur dorën (dikush) ((someone) has spoiled his/her hand; the quality has declined)

-E la pas dore (dikë a diçka) (to leave (someone or something) behind hand; forget about something)

-E mbledh (e rrudh) dorën (clench (shrink) the fist; start spending less)

-la dha veshët në dorë (dikujt) (to give (someone) the ears on hand; to berate some usually by tweaking their ears)

-la kthej dorën (dikujt) (to return (someone's) hand; not to accept someone's proposal for marriage)

-Më la me duar në ijë (dikush) ((someone) left me with my hands on my hip; have (one) in stitches)

-Fërkon duart (dikush) ((someone) rubs their hands; to gloat)

-Fut duart (diku) (he /she puts the hands (somewhere); to interfere)

\footnotetext{
${ }^{1}$ For ease of understanding, every Albanian expression is followed by its literal translation into English, and the corresponding English expression. The English expression is printed in italics and the body-part term in bold. All idiomatic expressions are in italics whereas the non-idiomatic ones are in normal.
} 
-I holloi duart (dikush) ((he/she) thinned their hands; to be very happy about something)

-Të jep dorë (diçka) (it gives (you) a hand; it is convenient, handy)

-l jep dorën e të merr (të rrëmben) krahun (dikush) (you give him/her the hand and they take (grab) the arm; give (someone) an inch and (someone) (will) take a mile)

-E ka lënë në dorë të fatit (dikë a diçka) (has left (someone or something) on the hand of fate; to abandon)

-E ka (e mban) dorën grusht (dikush) (someone) has (keeps) the hand clenched; to be stingy)

-Ç'i sheh syri ia bën dora (dikujt) (what the eye sees, the hand does; Jack of all trades)

-S'më bëjnë duart (për diçka) (my hands do not do; to be all thumbs)

-njëra dorë lan tjetrën, të dyja lajnë fytyrën (faqet) (one hand washes the other, together they wash the face (the cheeks); scratch my back and I'll scratch yours)

-la marr dorën (one takes the hand of something; get the hang of something)

-I ka duart të arta (dikush) ((someone) has golden hands; to be very good at)

-Dora e djathtë (e dikujt) (the right hand (of someone); right-hand man)

-la leu dorën (duart) (dikujt) (he /she lubricated the hand (the hands) (of someone); grease/oil sb's palm)

-la njomi (ia lagu) dorën (dikujt) ( he/she wetted (moistened) the hand; grease/oil sb's palm)

-E jep nën dorë (diçka) (he /she gives it under hand; grease/oil sb's palm)

-Me zemër në dorë (with heart on the hand; hand over heart)

-I lë dorë të lirë (dikujt) (leave (someone) free hand; give sb a free hand)

-Më doli nga dora (dore, duarsh) (diçka) (dikush) ((someone) (something) got out of my hand (hands); get out of hand)

-l jap (i hedh) dorën (një dorë) (dikujt) (give (cast) the hand (a hand) (to someone); give/lend a (helping) hand)

-E lidhi këmbë e duar (dikë) (bound (someone) feet and hands; bind sb hand and foot)

Here again we would like to make a clarification, although the two expressions may seem identical, their meanings differ, in Albanian the primary meaning is to render someone powerless not in the physical sense, but metaphorically, unlike the English.

-Me të dyja duart (with both hands; with both hands)

-I lava (i fshiva) duart (nga dikush a nga diçka) (I washed (wiped) my hands (from someone or something); wash one's hands of it)

Here again we want to make a clarification, the first meaning of the expression in Albanian is to be left without someone or something. The second sense is the same as the English one.

-Ka kaluar në shumë duar (diçka) ((something) has passed through a lot of hands; change hands)

-Rri (është) me duar të lidhura (dikush) ((someone) stands (is) with tied hands; tie sb's hands).

-Rri me dorë në xhep (to stand with hand in the pocket; put one's hand in one's pocket)

Here, again the meaning in the two languages is not the same; whereas in English you donate money to a charity or someone in need, in Albanian you simple buy your friends drinks or treat them to something special (beware of the false friend).

-Me dorë të hekurt (with iron hand; with iron fist/hand) 
-I ka duart të thara (dikush) ((someone) has his/her hands dried; have a hand like a foot)

-Vë dorën në zemër (për dikë) (put the hand on the heart (for someone); put your hand on your heart)

Here, gain the meaning in the two languages is not the same; whereas in Albanian you feel sorry for someone or you pity them, in English if you can put your hand on your heart and say something, you can say it knowing that it is the truth.

-Më shkau (më rrëshqiti) nga duart (nga dora) (dikush a diçka) ((someone or something) slipped (glided) from my hands (from the hand); slip through sb's fingers)

-Me presh në dorë (with leeks in hand; catch sb red-handed)

-Me duar në presh (with hands in leeks; catch sb red-handed)

-Me pelë për dore (with mare (the female of a horse) by the hand; catch sb red-handed)

-Hodhi dorë (dikush) ((someone) flung hand; to steal)

-Rri me duar lidhur (dikush) ((someone) stands with hands tied; fold one's arms/hands)

-E ka dorën të madhe (dikush) ((someone) has big hand; lay a finger on sb)

-Ka dorë (dikush) ((someone) has hand; lay a finger on sb)

-la lë në dorë (dikujt) (leave it in the hand (of someone); palm sb/sth off (on sh)

Here again we deal with a difference in meaning, in Albanian the primary sense of the expresssion is to entrust someone with something, the second coincides with that of the English.

After we explained the meanings of the expressions we pass to the issue of equivalence.

\subsection{Equivalence}

Since our analysis places Albanian and English side by side with Albanian being in the first position and then we see if the same expression can be rendered in English using the same body-part term "hand" we can distinguish three degrees of equivalence:

(1) Total equivalence is the same meaning (or at least the second meaning) of the Albanian expression is conveyed in English using the same term.

(2) Partial equivalence if the same meaning of the Albanian expression is conveyed in English using a different body-part term. Here we would like to stress the fact that there two kinds of partial equivalents, the first (a) where the body part shows a meronymic relationship with the Albanian dore (b) the body-part term used is totally different.

(3) Zero equivalence, i.e. there is an expression in English, but it does not make use of a body-part term, or for the same meaning of the Albanian expression the dictionaries do not have an equivalent English expression.

Examples of total equivalence

Albanian

English

-Ngre (çon) dorë (dorën) (kundër dikujt a kundër diçkaje) (lift (raise) hand (the hand) (against someone or something); lift/raise one's hand against $s b$ )

-Dora e djathtë (e dikujt) (the right hand (of someone);

Right-hand man)

-Me zemër në dorë (with heart on the hand;

hand over heart)

-I lë dorë të lirë (dikujt) (leave (someone) free hand;

give $s b$ a free hand)

-Më doli nga dora (dore, duarsh) (diçka) (dikush) ((someone) (something) got out of my hand (hands);

get out of hand) 
-I jap (i hedh) dorën (një dorë) (dikujt) (give (cast) the hand (a hand) (to someone);

\section{give/lend a (helping) hand)}

-Me të dyja duart (with both hands;

-Ka kaluar në shumë duar (diçka) ((something) has passed through a lot of hands;

-Rri (është) me duar të lidhura (dikush) ((someone) stands (is) with tied hands;

-Me dorë të hekurt (with iron hand;

-I ka duart të thara (dikush) ((someone) has his/her hands dried;

-Me presh në dorë (with leeks in hand;

-Me duar në presh (with hands in leeks;

-Me pelë për dore (with mare (the female of a horse) by the hand;

-Rri me duar lidhur (dikush) ((someone) stands with hands tied;

Second-degree equivalents

-I lava (i fshiva) duart (nga dikush a nga diçka) (I washed (wiped) my hands (from someone or something);

$$
\text { wash one's hands of it) }
$$

From what we see from the examples regarding the total equivalents we can see that even their structure is largely similar.

As far as partial equivalents are concerned we pointed out that we distinguish two kinds, those in which the body-part term has a meronymic relationship with the Albanian dorë, and those which feature a different body part.

Examples of partial equivalence

Albanian

English

-S'më bëjnë duart (për diçka) (my hands do not do;

to be all thumbs)

-njëra dorë lan tjetrën, të dyja lajnë fytyrën (faqet) (one hand washes the other, together they wash the face (the cheeks); scratch my back and I'll scratch yours) -la leu dorën (duart) (dikujt) (he /she lubricated the hand (the hands) (of someone); grease/oil sb's palm) -la njomi (ia lagu) dorën (dikujt) ( he/she wetted (moistened) the hand; grease/oil sb's palm) -E jep nën dorë (diçka) (he /she gives it under hand; grease/oil sb's palm) -Më shkau (më rrëshqiti) nga duart (nga dora) (dikush a diçka) ((someone or something) slipped (glided) from my hands (from the hand);

-E ka dorën të madhe (dikush) ((someone) has big hand;

-Ka dorë (dikush) ((someone) has hand;

-la lë në dorë (dikujt) (leave it in the hand (of someone);

Examples of zero equivalence

Albanian

- I dha duart (dikujt) (gave (someone) the hands; slip through sb's fingers)

lay a finger on $s b$ )

lay a finger on $s b$ )

palm sb/sth off (on sh)
English

kick out)

-la bëj me dorë (dikujt a diçkaje) (To wave one's hand (at someone or something); 
not to need someone or something anymore)

-Hedh gurin e fsheh dorën (dikush) ((someone) flings the stone and hides the hand;

\section{commit a wrongdoing but deny responsibility)}

-S'më bën dora (one's hand is unwilling to act, to pity someone or something;

to be unwilling to do something)

-U bë një dorë (dikush) (became one hand (someone);

to crouch out of fear, cold, problems)

-E ka dorën të shpuar (dikush) ((someone) has a pierced hand;

to spend money recklessly)

-Syri plot e dora thatë (the eye is full but the hand is dry;

to see a lot of things around but to be unable to buy)

-I nxjerr gështenjat (nga zjarri) me duart e botës (pull the chestnuts (out of the fire) with the world's hand;

pull the Isomeone's chestnuts out of the fire)

-E ka prishur dorën (dikush) ((someone) has spoiled his/her hand;

the quality has declined)

-E la pas dore (dikë a diçka) (to leave (someone or something) behind hand;

forget about something)

-E mbledh (e rrudh) dorën (clench (shrink) the fist;

start spending less)

-la dha veshët në dorë (dikujt) (to give (someone) the ears on hand;

to berate someone usually by tweaking their ears)

-la kthej dorën (dikujt) (to return (someone's) hand;

not to accept someone's proposal for marriage)

-Më la me duar në ijë (dikush) ((someone) left me with my hands on my hip;

have (one) in stitches)

-Fërkon duart (dikush) ((someone) rubs their hands;

to gloat)

-Fut duart (diku) (he /she puts the hands (somewhere);

to interfere)

-I holloi duart (dikush) ((he/she) thinned their hands;

to be very happy about something)

-Të jep dorë (diçka) (it gives (you) a hand;

it is convenient, handy)

-l jep dorën e të merr (të rrëmben) krahun (dikush) (you give him/her the hand and they grab the arm;

give someone an inch and someone (will) take a (mile)

-E ka lënë në dorë të fatit (dikë a diçka) (has left (someone or something) on the hand of fate; to abandon)

-E ka (e mban) dorën grusht (dikush) (someone) has (keeps) the hand clenched;

to be stingy)

-Ç'i sheh syri ia bën dora (dikujt) (what the eye sees, the hand does;

Jack of all trades)

-la marr dorën (one takes the hand of something;

get the hang of something)

-I ka duart të arta (dikush) ((someone) has golden hands;

to be very good at)

-Hodhi dorë (dikush) ((someone) flung hand;

to steal)

After anaylsing the data we can say that there are quite a few language-specific expressions (mostly those belonging to the third degree of equivalence) with this body-part term, e.g. the Albanian I dha duart (dikujt) (gave (someone) the hands meaning kick out), la bëj me dorë (dikujt a diçkaje) (to wave one's hand (at someone or something) meaning not to need someone or something anymore), Hedh gurin e fsheh dorën (dikush) ((someone) flings the stone and hides the hand; commit a wrongdoing but deny responsibility), S'më bën dora (one's hand is unwilling to act, to pity someone or something; 
to be unwilling to do something), $U$ bë një dorë (dikush) (became one hand (someone); to crouch out of fear, cold, problems), E ka dorën të shpuar (dikush) ((someone) has a pierced hand; to spend money recklessly), Syri plot e dora thatë (the eye is full but the hand is dry; to see a lot of things around but to be unable to buy), $E$ ka prishur dorën (dikush) ((someone) has spoiled his/her hand; the quality has declined), $E$ la pas dore (dikë a diçka) (to leave (someone or something) behind hand; forget about something), E mbledh (e rrudh) dorën (clench (shrink) the fist; start spending less), la dha veshët në dorë (dikujt) (to give (someone) the ears on hand; to berate some usually by tweaking their ears), la kthej dorën (dikujt) (to return (someone's) hand; not to accept someone's proposal for marriage), Më la me duar në ijë (dikush) ((someone) left me with my hands on my hip; have (one) in stitches), Fërkon duart (dikush) ((someone) rubs their hands; to gloat), Fut duart (diku) (he /she puts the hands (somewhere); to interfere), I holloi duart (dikush) ((he/she) thinned their hands; to be very happy about something), Të jep dorë (diçka) (it gives (you) a hand; it is convenient, handy), E ka lënë në dorë të fatit (dikë a diçka) (has left (someone or something) on the hand of fate; to abandon), Fërkon duart (dikush) ((someone) rubs their hands; to gloat), E ka (e mban) dorën grusht (dikush) (someone) has (keeps) the hand clenched; to be stingy).

However is this by no means something new to us, since as Sapir says, "Languages vary greatly in the nature of their vocabulary ... These changes go beyond the names of cultural objects. They are also implemented to mental world" ANNA WIERZBICKA (1997: p, 4) or as Konrad Adenauer puts it in lay terms "We live under the same sky, but we do not have the same horizon". That is to say, such expressions are an inseparable part of the language of a people and are the very bedrock upon which language rests and is cultivated, and since we conceive of the world around us in unique and different ways so we come up with expressions which most of the time have their equivalents in different languages but sometimes they do not. Thus, they can only be understood if one is part of the society where they are born and used, i.e. only if one possesses the right information to decode the meaning of the component words and transform them from individual literal words into a coherent sum of words on the basis of common cultural references. However, as we know, since we live in a global village and we are all interconnected cultural exchanges leave their own mark on the very medium that enables this exchange, the language. Consequently, some expressions have an "international passport". This makes the expressions of these two languages unique. As Herder, Johann Gottfried, (1966 [1772]: p, 154) says "Each [language] in its own way is both lavish and lacking, but, to be sure, each in its own way".

\section{Conclusions}

In this paper we analysed Albanian phraseological expressions formed with the use of body-part term dorë and saw the degree to which the same process is reflected (or not) in English. As the examples show the same concept is realized in different ways in the two languages. The reasons behind such reality are many but we all agree that we think differently and thus the outcome is different.

Out corpus albeit very small in scale sheds further light on the topic of culture and cognition and the mindset that these peoples inhabit and in turn how such cultures shape and are shaped by them. Although Albanian and English are part of the big Indo-European family of languages they are quite distant but in terms of language structure with Albanian being synthetic and English analytic with synthetic features. Such expressions carry the seal of authenticity in each language. They are unique creations of the two respective languages and transmit the popular wisdom accumulated generation after generation in their interaction with the outside world and reality. Equivalent expressions between the two languages do exist and warrant further exploration. Likewise, examples of zero equivalence are as or even more numerous which suggests that both languages employ different cognitive processes when communicating with the outside world all of this while utilising the human body with its constituent parts (more specifically the hand in our case) and its functions as an interface.

\section{References}

[1] ANNA WIERZBICKA, (1997) Understanding Cultures through Their Key Words, Oxford University Press.

[2] Fjalori i gjuhës së sotme shqipe (1980). Tiranë.

[3] Fjalori i shqipes së sotme. (1984). Tiranë.

[4] Gläser, Rosemarie. 1998. The stylistic potential of phraseological units in the light of genre analysis. In: Cowie, A. P. (ed.), Phraseology. Theory, analysis, and applications, 125-143. Oxford: Oxford University Press.

[5] Ilo Stefanllari, English-Albanian Dictionary of Idioms, Hippocrene Books, Inc. New York, 2000

[6] Thomai, J.(1999). Fjalor frazeologjik i gjuhës shqipe. Shtepia Botuese "Shkenca", Tiranë. 
[7] Thesaurus of TRADITIONAL ENGLISH METAPHORS Second edition P.R.WILKINSON, 2002

[8] Longman Dictionary of English Idioms, Longman group limited 1979

[9] Oxford Dictionary of Idioms, edited by Judith Siefring, Oxford University Press, 1999

[10] Herder, Johann Gottfried. 1966 [1772]. On the origin of language. Trans. John H. Moran and Alexander Gode. New York: Frederick Ungar.

[11] Dobrovol'skij, Dmitrij and Piirainen, Elisabeth (2005) Figurative Language: Cross-Cultural and Cross-Linguistic Perspectives. Elsevier, Oxford, UK. 